\title{
THE ROLE OF THE STATES IN ATOMIC DEVELOPMENT**
}

\author{
William A. W. Krebs† and Robert L. Hamilton $\ddagger$
}

I

Until comparatively recently, the development of the atomic energy industry has progressed almost as if state governments did not exist in the political organization of the country. Under the conditions which prevailed prior to 1954 , it is not surprising that they played so insignificant a role. Activities in the field were almost exclusively a concern of the national government: almost all important facilities were owned by the national government; means of finance were provided by the national taxing power; major policy decisions were made by national officials and were hidden from state governments by a cloak of high security; and private organizations, to the extent they participated in the development of the industry (which they did to a very great extent), functioned primarily as agents of the national government. State governments, accordingly, could reasonably remain unconcerned.

Such detachment on the part of the states, however, is no longer tenable today. With the passage of the Atomic Energy Act of $1954,{ }^{1}$ there have occurred three important changes, each of which has far-reaching significance for state governments: ${ }^{2}$

First, a new legal class of private parties active in the atomic energy field has been created, namely, licensees under the 1954 act. Heretofore, private persons and organizations operated atomic energy facilities and possessed special nuclear material and source material as employees, agents, or contractors of the national govern-

* The material presented in this article was assembled, in part, under a research grant from the School of Industrial Management Research Fund at the Massachusetts Institute of Technology, made possible by assistance from the Alfred P. Sloan Foundation. It is an expansion of ideas expressed by Professor Krebs in an address, entitled The Role of the States-A First Look, before the Atomic Industrial Forum in New York City, May 24, 1955, and in remarks before the Public Utilitics Section of the American Bar Association at the annual meeting of the Association in Philadelphia, August 23, I955.

† A.B. I938, LL.B 1941, Yale University. Member of the New York and Massachusetts bars; Associate Professor of Law, Massachusetts Institute of Technology School of Industrial Management; Executive Secretary of the New England Committee on Atomic Energy; and member of the Special Committce on Atomic Energy of the Bar Association of the City of New York. Formerly counsel to the Atomic Energy Commission and genieral counsel to the National Science Foundation.

$\ddagger$ A.B. 1948, Yale University; LL.B. I95I, Harvard University. Member of the Massachusetts bar; Assistant to the Manager of the Convair Atomic Industrial Development Project. Formerly Teaching Fellow at Harvard Law School and Research Associate at Massachusetts Institute of Technology School of Industrial Mangement.

${ }^{1} 68$ STAT. 921, 42 U.S.C.A. $\$ 2011-28 \mathrm{I}$ (Supp. I954). This statute is hereinafter referred to as the 1954 act.

2 These changes add to, rather than replace, the existing pattern of legal control of peaceful atomic development; with respect to military applications of atomic energy, the pre-existing pattern subsists in the main. 
ment. Henceforth, many of them will engage in similar activities in the capacity of licensees, incapable of invoking a federal immunity to shield themselves from state laws and regulations.

Second, the locus of initiative for many important decisions is shifting away from the national government. Heretofore, the power to determine the course of all major developments in the atomic energy field has rested exclusively with the national government. Henceforth, the capacity to make important decisions affecting atomic energy development will also be vested in hundreds of private corporations, state agencies, and state subdivisions.

A third change, attributable as much to the advancing state of atomic art as to the passage of the 1954 act, is in the kind and pace of atomic energy development. Nuclear reactors for the production of power are under construction. Increasingly they will be privately financed. Uses of radioactive isotopes are soaring. Various commercially attractive operations are on the horizon. Research fostered by both private and public funds is being pushed at an increasing tempo. And elements of competition are gradually making entrance upon the atomic scene.

From each of these changed conditions will emanate novel, challenging problems for state governments, some of which can be perceived today and some of which will undoubtedly remain unnoticed for a time. Although the full significance of these changes for the states can be foreseen only partially, it is possible, with respect to each of them, to indicate a measure of their impact. While separate analysis of these changes is necessary in order to understand their interplay, it should be remembered that in many situations, their effects will be overlapping and cumulative.

\section{The Change in Legal Status}

The great change in the law, relevant to this article, results from sections $4 \mathrm{I}$, IOI, x03, and ${ }_{04}$ of the I954 act, $^{3}$ which, for the first time, permit private ownership of facilities designed to produce or utilize special nuclear material; and from sections 53 and 54,4 which permit the AEC to make large quantities of special nuclear materials available to private parties for suitable purposes, under appropriate licenses issued by the Commission. The significance of this change can be illustrated by the case of a utility company which has decided to build and operate a power reactor. Unlike the contractor-operators at Hanford, Oak Ridge, or Savannah River, the utility company will, as a private entity rather than agent of the national government, be subject to state controls and policies on many sides, in addition to federal controls and policies-and in some cases, it may be caught in a cross-fire between them. Moreover, since "state controls and policies" are not necessarily a homogeneous, consistent set of regulations, but rather are more likely to be rules, regulations, and procedures formulated, in many instances, long prior to the Atomic Energy Act of 1954 and administered by a wide range of state agencies, the licensee may very well find them, as applied to its activities, at best uncoordinated and at worst

3 68 STAт. 928, 936, 937, 42 U.S.C.A. \$\$ 205I, 213I, 2133, 2134 (Supp. 1954).

68 Stat. 930, 931, 42 U.S.C.A. $\$ \$ 2073,2074$ (Supp. 1954). 
quite at odds with one another. Since each state agency is ordinarily charged by one or more statutes with responsibility for a limited number of specific activities or conditions, such diversity should not be unexpected. A company engaging in the exploitation of atomic energy and having activities which bring it within the jurisdiction of several state agencies can, therefore, anticipate the necessity for threading a careful way through the fabric of state control.

Specific problems can be isolated by listing separately each executive department, agency, board, and commission in a particular state and determining whether such organization is charged with responsibility over one or more phases of the activities of atomic energy licensees within the state. ${ }^{5}$ The following examples illustrate new state powers and responsibilities, some involving possible jurisdictional conflicts:

Heretofore, the AEC has had exclusive responsibility for controlling the radiation hazards created by the operation of its reactors. Once a private utility begins to operate a reactor, however, the state public health department, in addition to the AEC, may legitimately concern itself with possible hazards created for the public at large, and it may not apply the same safety standards as the AEC. In addition, the state labor department often has responsibilities for the occupational safety of the personnel at the installation, and it may apply safety standards which differ from those of both the AEC and the state public health department. ${ }^{\circ}$ A real conflict may possibly arise between the regulations-i.e., not only may one set be more stringent than another, but compliance with one set may necessarily involve violation of a different set.

Heretofore, there have been no reactors built by private utilities with their own money as additions to their generating capacity. Hence, state public utility commissions have not had responsibility for approving their construction or financing. Now, a state public utilities commission may have to issue a certificate of convenience and necessity before the utility can devote its funds to the construction of such a

\footnotetext{
'In Massachusetts, for example, each of the following state agencies will probably have to widen its field of activities to include problems arising from atomic energy development:

Public Health Department

Department of Public Utilities

Department of Banking and Insurance

Labor Department

Public Safety Department

Department of Industrial Accidents

Department of Taxation

Industrial Development Commission

Commerce Department

State Library Board

State University Board

State Planning Board

Port of Boston Authority

Airport Authorities

Aeronautics Commission

Highway Commission

Weather Control Commission

Agriculture Department

Department of Education

Conservation Department

Commission on Uniform State Laws

Commission on Interstate Cooperation.
}

This list includes organs of state government charged with educational and promotional functions as well as those with regulatory responsibility.

${ }^{8}$ In New York, for instance, the Department of Health adopted comprehensive regulations dealing with ionizing radiation, effective Sept. I, 1955, N. Y. STATE SANITARY Code c. XVI; the Department of Labor is in the process of adopting regulations establishing conditions for work in radiation areas, Proposed Industrial Code Rule No. 38, pending before the Board of Standards and Appeals; and the City of New York has additional regulations applicable to persons within its jurisdiction. SANITARY Cone, New York City Dep't of Health §roja. 
new facility. The state commission will have before it questions of considerable complexity and magnitude: Is it sound policy for the utility, at this time, to build into its system a generating facility of unknown reliability and clearly uneconomic function rather than wait five or ten years for the uncertainties to be resolved? What will be the proper allocation of the excess costs incurred in bringing atomic power into the system as between investors and rate payers, present and future? Are the consumers adequately protected against inadequate fuel-element supply? Can a utility participate in the construction and operation of a reactor located outside of the state and, therefore, beyond the jurisdiction of the commission? ${ }^{7}$

Heretofore, the location of new reactors was exclusively within the control of the AEC. Now, not only the state governments, but even local authorities and business interests will also be able to assert some degree of control. At the state level, one can expect the public utilities commission, the department of public health, and perhaps the state planning board, the department of conservation, and the department of agriculture to play a part in the ultimate decision. The local interests will find expression in special legislative acts, zoning regulations, building codes, private restrictions, and political mechanisms of many kinds. Whether these interests view a power reactor in the neighborhood as a prize to be sought or a nuisance to be abated may have considerable effect upon atomic power development in the state.

It is likely that the capacity of any given drainage basin to carry radioactive wastes from reactor coolant discharges is finite and will limit the number of power reactors which can be located on the particular river system involved. The adjustment of local, state, and interstate interests in the development of water supplies for agricultural, industrial, and consumer uses has, in the past, sometimes been regulated by interstate compact as well as by individual state agencies. State officials will, accordingly, play a central role in determining the best way in which to mesh such interests with the progressive utilization of such drainage basin capacity resulting from AEC approval of successive license applications.

Not all of the state activity engendered by the creation of the legal class of atomic energy licensees will be of a regulatory and control nature. The states have, or should have, as much interest in obtaining for their citizens the fruits and profits from the new industry as they have in guarding them against the potential hazards of careless utilization of atomic power. The appropriate state agencies now have good reason to undertake educational and promotional activities to call to the attention of the industrial leaders in their states the advantages to be gained through use of atomic power and radioactive isotopes in their operations, to encourage the education and training of their qualified citizens in the various specialities necessary to meet the demands of a growing industry, and to educate the public at large about the benefits to be obtained through the uses of atomic power. Such agencies can also publicize the adequacy of measures in effect to protect the public health and safety against potential radiation hazards.

${ }^{7}$ For a discussion of these and related problems, see Pike, Model State Law for Atomic Energy Regulation, 55 Pü. UTIL. Fort. 668 (I955). 
In short, all of the state agencies which have any control over, or responsibility to promote, any one or more of the manifold activities in which a private concern may engage in its utilization of atomic energy for peaceful uses have a role to play in connection with the development of this new industry. The general objective of each state should be twofold: to secure for its citizens as many of the benefits of the industry as possible, and to protect its citizens from its potential hazards. One can safely assume that the AEC will remain alert to its responsibilities in both of these areas on a national basis. The time has come, however, for each state also to become alert to its own responsibilities within its borders and to take steps to see that its laws and policies, at all levels of government, are realistically adapted to meet the needs of the new situation.

\section{The Change in Locus of Initiative}

The second new condition which has been suggested as having an impact upon state responsibilities is the change in the locus of the initiative for important decisions about atomic energy development-from the AEC to the managements of many diverse organizations, private and public. The incidence of this change will fall primarily upon the developmental and promotional functions which many state governments have assumed, and which may be of unique importance in the pattern of development in a new industry.

So long as atomic energy remained nationally directed, decisions as to the erection of new facilities, their location, and design were matters within the exclusive control of the AEC and were influenced primarily by considerations of national strategic and economic policy and possibly, to some extent, by political forces. Similar decisions, when entertained now by the management of a public utility company, however, will undoubtedly be substantially influenced by other considerations and through other channels. It would seem safe to observe that probable economic consequences will weigh heavily in the scales. For example, the decision to build a costly power reactor which will operate at a loss in an electric utility system is likely to be made sooner by a company in a high power-cost area than by one in a low power-cost area; likewise, it will likely be made sooner by a company in a state which taxes utility income than by one in a state which taxes utility property. And management, looking for a site, is likely to be more favorably inclined toward a state where the development agency is well-informed and aggressive in atomic energy matters than toward a state where the government is indifferent or ignorant of the unique needs, interests, and problems of the atomic entrepreneur. Variations from state to state in tax structure, labor markets, and treatment of foreign corporations will all be weighed, along with numerous other factors, many of which will be unique for the organization making the decision, such as proximity to a university or a market, or physical integration with other components of the company's plants. In this complex, the attitudes of state governors, legislators, regulatory commissions, municipalities, and the responsible public opinion to which they must react and which they, in turn, can shape, are, in part, the determinants of that intangible 
but significant "climate" of the state which can affect profoundly the speed and direction of its atomic growth.

To a certain extent, the states can participate directly in the development of atomic industry. In those states where power companies are run by municipalities or other governmental subdivisions, positive governmental leadership can pioneer the way, with the state treasury providing financial assistance in the interest of development for the benefit of all of its citizens. It is not inconceivable that a state might authorize construction of a power reactor in its own right as a means of meeting the high developmental costs of power reactors today, with an eye to distribution of the power produced and dissemination of the lessons in reactor technology learned to the existing power companies in its territory on some equitable basis. At the educational level, state universities can be supplied with research reactors, and research in problems of special interest to the state can be encouraged. 8 While the "climate" of the state, as assessed by a private organization weighing the comparative advantages of two or more states, is not something wholly under the control of the state government, there are areas in which the state government can take direct action.

The Change in Kind and Pace of Development.

The third new condition mentioned as having a profound impact upon state responsibilities is the change in the kind and pace of atomic energy development. By change "in kind," reference is made to the trend to private financing. It has been noted above that privately financed organizations will be the object of state regulatory and developmental activity. Private financing has further implications, however. In addition to creating private atomic activity to be developed and controlled, privately financed organizations will also create new private activity collateral to the atomic activity, which will engage further state action.

For example, the utility company proposing to operate a power reactor will have to have insurance. Clearly, the state and its municipalities have an interest in the type and extent of insurance coverage available for potential radiation hazards. What must be done to make available workmen's compensation insurance covering personnel at atomic energy plants on a realistic basis? What are the proper rates for fire and explosion insurance for a given type of reactor when no experience tables are available? Is state action the appropriate way to solve the problem raised by the need for public liability insurance in excess of the underwriting capacity of the private insurance industry? To what extent can a private utility company be permitted to be self-insured? Are present statutes of limitations of claims for injury arising out of radiation exposure realistic? State insurance commissions and other

\footnotetext{
${ }^{8}$ North Carolina, for example, has had a nuclear reactor in operation since 1953 at the North Carolina State College, where a program in nuclear engineering has been established and where, in July 1955, a special one-month course in Industrial Participation in Nuclear Power Developments was offered. On May 27, 1955 , Florida, following suit, adopted a statute appropriating $\$ 500,000$ to the University of Florida to engage in atomic research and acquire a reactor. Fla. Bill No. 304, Laws of I955.
} 
authorities clearly have a role to play in the effort to meet the pressing needs of the privately financed atomic energy industry for insurance of all kinds. ${ }^{9}$

Growing atomic enterprises will undoubtedly search for capital. Already, there has been considerable agitation for stricter controls over the issuance of securities by uranium mining corporations. What should be the policy of the states with respect to concerns whose key valuable asset is a revocable license to use government-owned special nuclear material, or to concerns having commercial activities all of which are still considered classified information? State "Blue Sky" commissions will have some part to play in this connection in atomic industrial development.

A fairly long-term demand for uranium appears to be a feature of mid-twentieth century life. An unprecedented uranium hunt, sparked by pegged federal prices for ore and bonus awards for new discoveries, has sent thousands of professionals and amateurs into the field. States in which such activity is under way may well have to face the question of whether their mining laws are adequate for the needs of the time. ${ }^{10}$

Experimentation in the processing of foods by use of ionizing radiation instead of heat is well under way today. When techniques become perfected, state agriculture and food and drug authorities will have new problems to face. While the AEC may have exclusive control of the processing operation from a health and safety point of view, there is a substantial question whether its authority or the scope of its effective administration extends to the channels of trade between wholesaler and corner grocery, once the food has left the processing plant.

As the number of industrial and other applications of atomic energy increases, there will be an increasing demand for new kinds of specially trained personnel. Experts, such as "health physicists," may be required to inspect or supervise certain operations. State civil service commissions and boards of professional registration will undoubtedly have to adjust their categories and establish new standards to accommodate the new species of atomic-age professionals.

As privately owned reactors come into operation, private institutions will gradually take over an increasing share of the business of producing radioactive isotopes. State highway, airway, and waterway authorities may have to exercise control over shipments of radioactive materials within the state over which the federal authorities exercise no jurisdiction.

Charitable institutions, such as hospitals, universities, and research foundations, utilize isotopes and are beginning to apply for licenses to build and operate reactors. ${ }^{11}$ In many, if not a majority, of the states, such organizations enjoy some degree of

\footnotetext{
${ }^{\circ}$ See Preliminary Report of the Insurance Study Group to the Atomic Energy Commission, AEC Release No. 662, July I3, 1955 .

${ }^{10}$ In Texas, such an evaluation has been made by a subcommittee of the Mineral Law Section of the State Bar of Texas, entitled Mineral Laws of the State of Texas in Relation to Fissionadle MaTERIALS (I955).

${ }^{11}$ Five of nine applications received by the AEC from private parties in the first six months of 1955 for licenses to construct atomic energy facilities were submitted by charitable institutions. Sce AEC Eighteenth Semiannual Rep. 103 (1955).
} 
immunity from tort claims. ${ }^{12}$ In the light of the potential hazards involved in utilization of atomic energy, such legal immunity would appear to deserve careful reexamination by the state legislatures.

State civil defense authorities will be likely to have a great interest in the number of atomic energy installations in the state, the degree to which the state is sophisticated in the uses of atomic energy and the practices necessary for radiation hazard control, the availability of trained personnel and adequate radiation detection equipment, and the general level of understanding of radiation hazards at the command of the populace. Defense officials may well command political, if not legal, forces which will affect atomic energy development in any given area.

Private groups are already in competition with one another in the atomic business, with respect to both large projects, such as building power reactors, and small items, such as manufacturing radiation detection equipment. Competition inevitably leads to cost-consciousness, which, in turn, tends to induce competitors to economize by reducing expensive safety practices to minimum standards. Thus, complacency on the part of the states, whether reasoned or unreasoned, has become entirely inadequate today.

Although not a matter to be developed here, it should be pointed out that these collateral activities, which will inevitably occur with the private development of atomic energy and will prompt the types of state action noted above, will also invoke collateral federal activities by agencies other than the AEC. Regulations concerning the shipment of radioactive materials by the Interstate Commerce Commission, the Civil Aeronautics Board, and the Post Office Department are obvious examples. ${ }^{13}$ Licensees who transmit or sell electric energy in interstate commerce are expressly made subject to the regulatory provisions of the Federal Power Act under section 272 of the Atomic Energy Act of $1954^{14}$ And it may be expected that other federal agencies will come to have a tangential part to play in the development and regulation of the industry.

What has been said about changed conditions of all kinds makes it evident that the state authorities have a significant role to play in the peacetime development of atomic energy. The accelerating pace of atomic development ${ }^{15}$ underscores the

${ }^{12}$ See Immunity of Nongovernmental Charity from Liability for Damages in Tort, Annot., 25 A.L.R. $2 \mathrm{~d} 29$ (1952).

${ }^{13} 49$ C.F.R. $\$ \$ 7$ I-78 (Supp. I954); I4 C.F.R. $\$ 49$ (I952); 39 C.F.R. $\$ 35.16 \mathrm{a}$ (1949). Less obvious examples are Coast Guard Regulations, 46 C.F.R. $\$ 146$ (1953); and Labor Department Child Labor Regulations. 29 C.F.R. \$4.57 (Supp. I954).

14 68 STAT. 960, 42 U.S.C.A. \$20I9 (Supp. I954).

${ }^{15}$ In the first six months of 1955 , the AEC received nine applications for licenses to construct atomic energy facilities and three to use special nuclear materials for other purposes. See AEC ErGrrEENTH Semiannual Rep. 103-04 (1955). The uses of radioactive isotopes are also steadily increasing: between August 2, 1946, and December 31 , 1953, 12,162 curies of radioactive isotopes were distributed, see AEC Seventeentu Semiannual Rep. 93 (1955); between January I and November 30, 1954, 14,698 curies were distributed, ibid.; and in the first five months of $1955,17,730$ curies were distributed. See AEC Eighteenth Semiannual Rep. I2x (1955). Further, according to the Survey of Materials, Equipment and Personnel for Atomic Energy Development, published by the Atomic Industrial Forum, Inc., in April I955, industry and other private organizations can be expected to spend $\$ 300-500$ million of 
immediacy with which many of these new problems must be dealt if a state is to experience an orderly, effective development and regulation of atomic energy within its borders instead of a disorderly patchwork of stop-gap measures and countermeasures, designed to meet specific problems here and there, without thorough comprehension of the total needs of the situation.

II

The basic question confronting a state, as a result of the passage of the Atomic Energy Act of 1954, is the proper delineation of the area over which the state now has power and responsibility for governmental action. Under our system of government, in which the national government is granted specified powers only but is supreme within its proper sphere of action, the entire residue of governmental powers and responsibilities inheres in the state governments, subject to certain constitutional limitations. Hence, the question invokes a twofold analysis: a determination of the type and scope of powers over atomic energy development vested in the national government by the Constitution; and a determination whether Congress, in passing the 1954 act, exercised its constitutional powers partially, fully, or exceeded them.

The constitutional basis upon which the act rests are several: Two great, sweeping powers of the national government which Congress utilized are the war power and the commerce power; lesser powers are the power to dispose of government property, the power to grant patents, the power to make arrangements with foreign nations, and probably others, including the power to provide for the general welfare, if that be a separate power. ${ }^{16}$

Because the 1954 act rests on several constitutional bases and is directed toward a number of specific ends, from the development of military potential to the granting of operator's licenses and the sale of electric power, it is not fruitful to speculate about the constitutional power of the national government in this area in general. Different parts of the statute will rest upon different configurations of constitutional powers. In fact, the Supreme Court, the final arbiter of questions concerning the extent of national and state powers under the Constitution, under its rule of entertaining only questions necessary to the solution of actual cases and controversies, can be expected to adjudicate specific disputes by determining, first, what part the I954 act plays in the solution of each and, next, whether the provision of the act relied upon was within the constitutional competence of Congress. And since section $28 \mathrm{I}$ of the act ${ }^{17}$ contains a separability clause, even if the Supreme Court should invalidate part of the act as exceeding the proper ambit of congressional power, other unrelated sections of the act would be unaffected thereby.

nongovernmental funds on nuclear research and development during the five-year period 1954-58, inclusive. Moreover, government expenditures over the same period are likely to be scveral times this figure, exclusive of the weapons program, and are bound to produce technological advances capable of supporting industrial development on a constantly broadening basis. Sec id. at 8 .

${ }^{18}$ See $\$ \S 2$ and 3 of the I954 act, 68 STAT. 921, 923, 42 U.S.C.A. $\$ \$ 2012,2013$ (Supp. 1954), which set forth the congressional findings and the purpose of the act.

${ }^{17} 68$ STAT. 960, 42 U.S.C.A. \$2011 note (Supp. 1954). 
Assuming, however, that no part of the 1954 act will be held unconstitutional ${ }^{18}$ (an assumption which seems to be perfectly safe ${ }^{19}$ ), there will still arise the following questions with respect to any given portion of the pattern of control:

Did Congress intend to pre-empt certain areas of atomic energy regulation from which the states are to be precluded?

If Congress so intended, what are the limits of the pre-empted areas?

If Congress so intended, is the pre-emption effective immediately or only after the AEC has affirmatively acted to implement congressional intent?

If Congress so intended, may the states regulate matters within the preempted areas if the AEC declines to regulate such matters, either expressly or by silence?

If Congress so intended, may the states adopt rules consistent or identical with the federal regulation?

These are questions of statutory construction. ${ }^{20}$ The I954 act contains no clear expression of congressional intent on these matters with respect to peacetime development of atomic energy. Accordingly, to determine such questions, the courts may be expected to look to a number of other criteria in addition to the language of the act itself, namely: legislative history of the act; ${ }^{21}$ whether the AEC has been given statutory directives or only authority; ${ }^{22}$ policy considerations of uniformity versus diversity of regulation, and of centralized versus localized administration; ${ }^{23}$ the extent to which an over-all scheme of federal regulation has been established; ${ }^{24}$ the consequences of alternative possibilities; ${ }^{25}$ and perhaps others.

As with the questions of constitutional power, the foregoing questions must be examined with respect to each area of proposed state action, rather than with respect to state action in general. Prior to final determination of such questions, by unambiguous expression of congressional intent or by definitive court decision, therefore, it is necessary to proceed with a painstaking analysis of the relevant factors involved in each proposed state action and apply the several criteria noted above in order to reach sound conclusions as to its proper scope.

${ }^{18} \mathrm{See}$, in this connection, Estep, Federal Control of Health and Safety Standards in Peacetime Private Atomic Energy Activities, 52 Mrcr. L. Rev. 333 (1954), for a detailed discussion of the extent of congressional power to regulate a field which has traditionally been considered within the police powers of the states.

${ }^{10}$ This is not to say that the application of the statute may not, under some circumstances, be held to be unconstitutional, but only that it is unlikely that the Supreme Court will hold any part of the 1954 act to be invalid, per se, as violative of the Constitution.

${ }_{20}$ In most instances in the atomic energy field, it should be noted, we are not confronted with the problem of the scope of a state's power to act in the absence of congressional action. Cf. Cooley v. Board of Wardens, 19 U.S. (12 How.) 299 (185I).

${ }^{31}$ Cf. First Iowa Hydro-Electric Cooperative v. FPC, 328 U.S. 152 (I946).

${ }^{22}$ Cf. Oregon-Washington R.R. \& Navigation Co. v. Washington, 27o U.S. 87 (r926). But see H. P. Welch Co. v. New Hampshire, 306 U.S. 79 (I939).

${ }^{23}$ Cf. Rice v. Santa Fe Elevator Corporation, 33 I U.S. 218 (1947).

${ }^{26}$ Cf. Hines v. Davidowitz, 312 U.S. 52 (194I); Cloverleaf Butter Co. v. Patterson, 315 U.S. 148 (I942).

${ }^{25}$ Cf. First Iowa Hydro-Electric Cooperative v. FPC, stupra note $2 \mathrm{r}$. 
III

It is apparent that the first task of state authorities is to institute an orderly and thorough examination of the relationship of the changes described above upon each existing area of state function and to appraise imaginatively the need for state activity of types and in areas not now foreseen. Then, policies should be developed and mechanisms created to coordinate interstate and regional interests, and ways should be found to integrate those interests with the national atomic energy program.

To date, the state initiative with respect to atomic energy matters has been exercised in one of two general ways. Several states, which as of August I955 included the New England states, Texas, Michigan, and Illinois, have been impressed with the need for study of the over-all problem of integrating state and national atomic energy programs and have launched special studies to provide the background for a coordinated, over-all approach to its solution. Other states, such as New York, New Jersey, Pennsylvania, California, North Carolina, Florida, and others, have been impressed with the need for specialized state action in one or more specific areas-for the most part, that of health and safety regulations-and have acted accordingly. ${ }^{28}$ It will be useful to explore in some detail the problems which confront state authorities under both approaches.

That there would be an impact upon the states generally as a result of the atomic revolution now in progress was apparently first recognized in New England. In December 1953, a bill was introduced into the Massachusetts legislature to establish an atomic energy commission at the state level. ${ }^{27}$ Its principal objective was to focus the attention of the state government upon the manifold opportunities and responsibilities that would arise in the event that amendments to the Atomic Energy Act of 1946 , which were then under discussion in Congress, should become law. The bill was not enacted.

In February 1954, however, the New England Governors' Conference appointed a committee of twelve distinguished New England citizens to be a New England Committee on Atomic Energy, ${ }^{28}$ whose duty it was to study and report on both the area's potentialities for atomic energy development and the opportunities and responsibilities of the state governments, industries, educational institutions, and citizens which should be anticipated. In both its interim report in December 1954 and its final report in July I955, this Committee strongly recommended the enactment of a state atomic energy law during the I955 sessions of the state legislatures. ${ }^{20}$ The form of model state law proposed, together with the comments included in the report, is fully set forth in Appendix I.

The first objective of the model act, set forth in sections $I(a)$ and 2 , is to estab-

${ }^{20}$ Mineral laws and developmental activities appear to be the next most popular areas for state action.

${ }^{28}$ Mass. H. Bill No. 85I (1953).

${ }^{28}$ Members of the Committee were: Karl T. Compton, Chairman (deceased); Hartley Rowc, Succeeding Chairman; Ralph D. Booth; Wallace Fay; Leslie R. Groves; Robert N. Haskcll; Frank D. Merrill; Sumner Pike; Arthur L. Quirk; O. P. Robinson, Jr.; Shields Warren; and William Webster.

${ }^{20}$ See New England Committee on Atomic Energy, Atomic Energy and New England 59 (1955). 
lish in the state a single, harmonious pattern of atomic energy regulation, under the aegis of either federal or state law. Section 2 contains substantive provisions designed both to insure automatic coordination of federal and state regulation and to eliminate the possibility of a jurisdictional no-man's land. It appears to be beyond question that this objective is highly desirable. Effective formulation of this objective in writing, however, presents difficult drafting problems. ${ }^{30}$

The second objective of the model act, set forth in sections $\mathrm{r}(\mathrm{b})$ and 3 , is to initiate an orderly, comprehensive review of state functions and responsibilities that may be affected by atomic energy development, by specifically requiring each major administrative unit of the state government to make such a review of its functions and to present appropriate recommendations on the subject to the governor. The importance of this type of action has already been noted, but it should further be observed that such an undertaking is no mean task. An adequate survey may well require the employment of persons possessing knowledge about atomic energy who are not ordinarily at the command of the administrative units making the studies. If fruitful results are to be achieved, not only must the appropriate agencies be given the responsibility for making such studies, but the agencies must be provided with enough money to insure that the studies are carried through, and the responsible official in each agency must be sufficiently apprised of the importance of the program so that it will be carried through without undue delay.

The third objective of the model act, set forth in section 4 , is to provide a focus for the development of state policy in atomic energy matters by creating, on the staff of the governor, the office of Coordinator of Atomic Development Activities. The coordinator is to serve as adviser to the governor with respect to atomic industrial development within the state and as deputy of the governor in matters relating to atomic energy. He is given the duty of coordinating the studies, recommendations, and proposals of the departments of the state government and its subdivisions, and of providing liaison between his state, its sister states, and the AEC on atomic energy matters.

The Committee's comment concerning the creation of this office is worth repeating here for emphasis:

This section is premised on the proposition that what is everybody's business is nobody's business and therefore seeks to make sure that atomic development and regulation is somebody's business. The office of the Coordinator . . . is proposed so that at least one person in a central position in the State Government will be responsible for seeing that the way is cleared for atomic development and that this is done without jeopardizing the public interest.

To this comment, it should be added that the success of such a scheme will turn, in large measure, upon the calibre of person selected for the position of coordinator and the financial resources placed at his disposal. Upon his shoulders, primarily, will lie the responsibility for the "climate" of the state in atomic energy matters.

${ }^{30}$ See id. at 63 . 
Probably a considerable part of his efforts will be directed along "public relations" lines, requiring him both to display initiative, imagination, and diplomacy and to do a great deal of assembling and disseminating of information pertinent to the field. There is a danger that the potential benefits to be achieved through the coordinator will be lost if the person selected is already loaded with business or governmental responsibilities and if he is given neither office nor staff nor salary commensurate with his position. ${ }^{31}$ Even in states where the prospects for the use of atomic energy for power generation seem quite remote, there is bound to be a number of industrial or agricultural establishments which can benefit from utilization of new processes or techniques involving radioactive isotopes. On this point, one may well heed the recent advice of Sumner Pike, former AEC Commissioner ${ }^{32}$

The writer has had the experience of being fairly close to the subject [of atomic energy], since he was appointed to the original federal Atomic Energy Commission in 1946 . About the only dependable lesson he has drawn from the experience is that the subject won't stay hitched, predictions are frequently obsolete before they get into print, and that constant vigilance, combined with flexibility, seems to be the only policy which pays off.

The achievement of constant vigilance combined with flexibility of approach in a constantly shifting, developing industrial field requires the full time services of high calibre personnel-not a paper assignment of responsibilities to a figurehead.

As of August 1955, the report of the New England Committee was the most comprehensive study published on the implications of atomic energy for the states. The Texas Legislative Council published a somewhat similar report in May 1955 on the implications of atomic energy development for Texas and included the New England Committee's draft of a model statute as an appendix to its report without endorsing or criticizing it. ${ }^{33}$ A special committee appointed in Michigan by Governor Williams to study the problem for that state submitted a terse report in the spring of 1955 , stating that state legislation in the field was premature. ${ }^{34}$ The Illinois legislature in 1955 authorized the creation of an Atomic Energy Study Commission, ${ }^{35}$ but, to date, this group has not had time to complete its work. Without legislative direction, the Governor of Texas appointed a special advisory committee on atomic energy in September 1955, and the Governor of New York appointed an Atomic Energy Council in November 1955 .

Legislative response to the model statute proposed by the New England Committee has been favorable. Maine adopted a statute on March I8, I955, closely patterned after the model law; ${ }^{36}$ and New Hampshire ${ }^{37}$ and Connecticut ${ }^{38}$ did likewise

${ }^{31}$ So far, the New England states have not provided substantial financial support for their atomic energy programs. See notes $36,37,38$, and 39 infra.

${ }^{32}$ Pike, supra note 7 , at 673 .

${ }^{33}$ See Staff Research Report to the Texas Legislative Council, Implications of Atomo Energy

FOR TeXAs (1955). A supplement to this report was issued in November 1955.

${ }^{34}$ See Michigan Atomic Energy Study Committee, Report to Governor Williams (ig55).

${ }^{35}$ Ill. S. Bill No. 577, Laws of 1955.

${ }^{30} \mathrm{Me}$. Acts, I955 c. I05. The coordinator is given no salary, and no money is appropriated for his use in performing his statutory duties.

${ }^{37}$ N. H. Acts, 1955, c. 28I. The position of coordinator is to be conferred on the head of one of 
on August I and August II, respectively. Rhode Island, ahead of the other New England states, passed a state atomic energy law in January r955, not based upon the model statute, but containing provision for a five-man state atomic energy commission, with duties similar to those given to the coordinator under the model statute. ${ }^{39}$ No action has been taken in Vermont. And the model statute was not introduced in the 1955 session of the Massachusetts legislature; instead, it passed only a statute relative to radiological safety ${ }^{40}$ and a resolve concerning study of location of "atomic plants" in Massachusetts. ${ }^{41}$

A discussion of state planning to accommodate its pre-existing policies and laws to the atomic age would be incomplete without mention of the points of contact which each state will have with the federal government. The AEC is not unaware of the problem of interleaving its policies with those of the states with respect to peaceful applications of atomic energy. In July x955, it invited representatives of the governors of the forty-eight states to Washington to discuss the problems of state and federal cooperation. ${ }^{412}$ Particular emphasis was placed upon the health and safety regulations which the AEC had then just published in the Federal Register. ${ }^{42}$ The meeting served as a good introductory session for the officials of the state and federal governments who will have to work together with these matters in the future. In the federal government, the primary contact point for the states is the Division of Civilian Application of the AEC, which superseded both the Licensing Division and the Industrial Liaison Branch of the Reactor Development Division. A secondary point of contact is the Inspection Division. A third is the Isotopes Division, which still maintains its own offices for processing applications for isotopes and its own inspection staff. For smooth working relations between nation and state and for most efficient development of the industry, it is important that the responsibility in the AEC for coordinating federal policy development with that of the states and for providing liaison between the AEC and the states be focused in one division of the agency. It is just as true with the national government as it is with the states that "what is everybody's business is nobody's business."

At present, the Division of Civilian Application is the primary office to which a state coordinator, or like official, should turn to attack the problems of federalstate adjustment. However, the responsibility for providing a qualified state official

the existing state departments and is to be unpaid. One thousand dollars is appropriated for secretarial and similar expenses.

${ }^{38}$ Conn. Pub. Acts, June Spec. Sess., 1955, No. 46 . The coordinator is paid twenty dollars a day while actually performing his functions as such, but otherwise is given no salary. Five thousand dollars is appropriated to carry out the purposes of the act.

${ }^{30}$ R. I. Pus. LAws, I955, c. 3416. The commissioners are to be unpaid. Five thousand dollars is appropriated for expenses for the first fifteen months. The commission is responsible for conducting studies, but no provision is made for coordinating federal and state jurisdiction over atomic energy activities.

${ }^{10}$ Mass. Acts and Resolves, 1955, c. 335.

${ }^{\leftrightarrow 1} I d .$, c. 88 .

41a The AEC has made available a record of this meeting, entitled, Conference of State Representatives on the AEC Licensing Program, July 13 and 14, 1955, Summary of Proceedings.

120 Fed. Reg. 510x (1955), amending ro CFR Part 20. 
to deal with those problems and to meet the AEC half-way remains with the states. Coordination cannot be achieved through federal action alone.

\section{IV}

The creation of a state coordinator or a state atomic energy commission is but a first step toward development of sound state policies for atomic energy. Such a step will not solve the many problems of adjustment noted above; it will only provide an agency responsible for their systematic solution. The problems remain to be worked out, one by one, with due consideration for the unique elements in each. State regulation for the protection of health and safety against the hazards of ionizing radiation is one major problem which is already being actively considered both by the fedderal government and by a number of states. We have, therefore, selected it for more extended treatment, as an example of the role states will play in atomic energy development.

From the initial mining of uranium ore to the final dispersal or decay of radioactive materials, by-products, and isotopes produced from it, certain risks of radiation exposure are present to the health and safety of both the workmen engaged in the industry and also, often, the general public at large. A workman in a uranium mine may, over a period of time, become ill from excessive inhalation of radon gas. Persons working in plants where uranium ore is processed, where U-235 is separated from U-238, where fuel elements for reactors are fabricated, or where reactors convert fissionable material into power all run a risk of accidental exposure to excessive radiation, either by direct radiation or by the uncontrolled escape of radioactive particles. The risks to the general public are highest in connection with the operation of the chemical separation plants and reactors and with the disposal of radioactive waste products. The largest present source of hazard from private atomic energy activity probably results from the widespread use of radioactive isotopes in industry and in medical research and therapy.

Regulation to insure adequate protection against the potential hazards of ionizing radiation is complicated because of several factors: radiation cannot be detected by human senses, but requires specialized equipment to be located and measured; exposure has a cumulative effect upon the human organism; different types of radioactive substances produce different types and intensities of radiation and have different rates of decay; different types of radiation affect the human body differently; each type of radiation is more hazardous to certain parts and organs of the human body than to the rest of it; deleterious effects of excessive exposure may not become evident in the human organism until long after exposure takes place; and the deleterious consequences may extend to future generations because of the effect of radiation upon genetic processes. Each of these factors tends to make the experts in the field conservative; consequently, adopted standards. are likely to contain a large margin for error. In addition, the scientific community is constantly gaining additional experience in matters of radiation protection; the generally recognized standards of 
safe practices to minimize radiation hazards are under constant re-evaluation, and, from time to time, they change.

One unique aspect of this problem is that it has existed for some time and has already been the subject of considerable attention. While information about the hazards of radiation has never been common knowledge, those of the scientific and medical professions who work with radiation have been aware of the hazards of ionizing radiation at least since the I920's. In the United States, in I929, there was established an Advisory Committee on X-Ray and Radium Protection, sponsored by the National Bureau of Standards. Its members were drawn from professional and commercial associations interested in the use of radioactive substances, primarily radium, and in the production of radiation by other means. Prior to World War II, this Committee had produced handbooks setting forth procedures for protection against specific hazards then encountered. Today the Committee is called the National Committee on Radiation Protection and is composed of experts in the field of radiation protection from the American College of Radiology, American Medical Association, American Radium Society, American Roentgen Ray Society, National Bureau of Standards, National Electrical Manufacturers Association, Radiological Society of North America, the United States Army, Navy, Air Force, Atomic Energy Commission, and Public Health Service, and certain representatives at large. ${ }^{43}$ Since 1946 , it has revised all of the earlier handbooks and produced a number of new ones. ${ }^{44}$

In the field of radiation protection, therefore, there exists a nationally recognized body of authority and cadre of established experts to guide the formulation of an effective code. The NCRP, itself, is a voluntary organization with no regulatory or control authority over anyone. It considers its main purpose to be the establishment of the basic principles and philosophy of radiation protection; and it volunteers to assist any group faced with the problem of establishing practices to reduce radiation hazards. Recently, the NCRP has extended its work beyond the field of establishment of basic principles. Under pressure from state officials who desire state regulation of radiation hazards, it is in the process of publishing a handbook, entitled The Regulation of Radiation Exposure by Legislative Means, which will contain not only the Committee's conclusions as to basic principles, but also suggested forms for a State Radiation Protection Act and for regulations under it.

\footnotetext{
${ }^{13}$ See Taylor, State Control of Protection Against Ionizing Radiation, 71 Am. J. Roentgen. 69I, 698-99 (I954).

6 The currently effective handbooks are: $\mathrm{H}_{4} \mathrm{Y}$, Medical X-Ray Protection up to Two Million Volts (i949); H 42, Safe Handiing of Radioactive Isotopes (1949); H 48, Control and Removal of Radioactive Contanination in Laboratories (i95I); H 49, Recommendations for the Waste Disposal of Phosphorus-32 and Iodine-I3I for Medical Users (195I); H 5I, Radiologicai Monitoring Methods and Instriments (I952); H 52, Maximum Permissible Amounts of Radioisotopes in the Human Body and Maximum Permissible Concentrations in Air and Water. (I953); H 53, Recommendations for the Disposal of Carbon-I4 Wastes (1953); H 54, Protection against Radiations from Radium, Cobalt-6o, and Cestum-137 (I954); H 55, Personnel Protection for BetatronSynchrotron Radiations up to too Million Electron Volts (1954); H 56, Safe Handling of Cadavers Containing Radioactive Isotopes (1953); H 58, Radioactive-Waste Disposal in the Ocean (i954); H 59, Permissible Dose from External Sources of Ionizing Radiation (1954). See Taylor, supra note 43 ; at 701 .
} 
Before studying the role of the states in this field, however, one must take into account existing federal action. Working closely with the NCRP on the formulation of substantive provisions, the AEC published its proposed regulation on Standards for Protection against Radiation in the Federal Register in July $1955 .^{45}$ General authority for the promulgation of such a regulation is found in section $\operatorname{x6r}(\mathrm{b})$ of the 1954 act, $^{46}$ which empowers the AEC to:

... establish by rule, regulation, or order, such standards and instructions to govern the possession and use of special nuclear material, source material, and byproduct material as the Commission may deem necessary or desirable to promote the common defense and security or to protect health or to minimize danger to life or property. . . ;

as well as in specific provisions to similar effect dealing with arrangements to assist research, ${ }^{47}$ production of special nuclear material, ${ }^{48}$ the distribution of special nuclear material,$^{40}$ the distribution of source material, ${ }^{50}$ the distribution of by-product material, ${ }^{51}$ and the licensing of utilization and production facilities. ${ }^{52}$

The regulation contains three key substantive sections. The basic section, entitled Permissible Doses and Concentrations, specifies maximum permissible doses of radiation to which individuals in controlled areas may be exposed and maximum concentrations of radioactive material which may be permitted to be created in uncontrolled areas, to remain on exposed surfaces, or to be disposed of into air or water beyond the effective control of the licensee. The other two substantive sections, dealing with Hazard Control and Waste Disposal, contain certain required means (some specific, some general) to be followed in attaining the ends set forth in the preceding section. The section entitled Hazard Control requires, in general, that certain personnel likely to receive specified high doses of radiation or airborne radioactive material be required to use personnel monitoring equipment or respiratory protective equipment; that radiation areas and containers in which radioactive material is stored or transferred be posted with certain caution symbols and signs; that licensed material in noncontrolled areas be stored in locked and secured containers; and that individuals working with or in proximity to licensed material be instructed in the safe handling of such material, in the use of monitoring equipment and safety devices, and in emergency procedures. The third basic section of the regulation, entitled Waste Disposal, sets forth criteria to be observed in disposal of radioactive material into the ground, the ocean, and public sewers. The regulations are flexible, in that the AEC may grant to any licensee such exemptions from the requirements of the regulation as it determines are authorized by law and will not endanger life or

45 See note 42 supra.

468 STAT. 948, 42 U.S.C.A. \$220I(b) (Supp. r954).

${ }^{17} \S 3 \mathrm{I}$ (c), 68 STAT. 927, 42 U.S.C.A. \$205I(c) (Supp. 1954).

s8 $\$ 45(\mathrm{~b}),(\mathrm{c}), 68$ StaT. 928, 42 U.S.C.A. \$206I (b), (c) (Supp. I954).

$19 \$ 53(\mathrm{e})(7), 68$ STAT. 930, 42 U.S.C.A. $\$ 2073$ (e)(7) (Supp. 1954).

${ }^{\text {Бо }} 6_{3}$ (b), 68 STAT. 933, 42 U.S.C.A. $\$ 2093$ (b) (Supp. 1954).

51 \$ 8I, 68 STAT. 935, 42 U.S.C.A. § $211 \mathrm{I}$ (Supp. 1954).

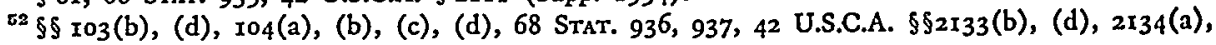
(b), (c), (d) (Supp. 1954). 
property, and reserves the right to impose upon any licensee such additional requirements as it deems appropriate to protect health or minimize danger to life or property.

Two basic and quite different questions confront a state with respect to health and safety regulation for protection against potential radiation hazards: What action, if any, can a state legally take, in view of the above federal regulations? And what action, if any, should a given state take under the circumstances?

The first question raises legal issues which have been alluded to generally above. It is the opinion of the writers that to the extent that federal control over regulation for protection against radiation hazards has been asserted in the I954 act, Congress intended that it be exclusive. ${ }^{52}$ The following factors seem to compel this conclusion:

(I) Under the I946 act, the national government clearly exercised exclusive control in this area. Modification of such a regime would, accordingly, seem to require explicit language to that effect. But there is no such language in the I954 act; instead, extensive instructions are given to the AEC in this regard, and any possible role for the states is completely ignored.

(2) Radiation hazards, especially those arising out of operation of power reactors, are not local in nature, but can cause danger to multistate areas.

(3) Uniformity of regulation in this field is highly desirable.

(4) There is a relatively small number of persons in this country competent to assess potential radiation risks; and, as of the effective date of the 1954 act, the AEC had most of these persons at its command.

Thus, state regulation in this area which conflicts with the federal regulation would appear to be superseded thereby. ${ }^{53}$ And, although no close analogies appear to be invocable, it seems clear that the Supreme Court would hold the I954 act, so construed, to be a valid exercise of war and commerce powers, and not unconstitutional. ${ }^{54}$

In this situation, three clear-cut, rational, general courses can be followed by any state considering the problem of protecting its citizens from potential radiation hazards. The first is to do nothing, relying upon the protection afforded by the AEC regulations and practices. The second is to adopt laws and regulations to protect the state's citizens from potential radiation hazards not regulated by the AEC-to "take up the slack" in the federal program, to use a popular phrase. The third is to adopt laws and comprehensive regulations overlapping all federal control and also regulating the areas not touched by the federal authorities.

E2a To date, the AEC has declined to adopt an official position on this question. See remarks prepared by Harold L. Price, Director, Division of Civilian Application, AEC, for presentation before the Atomic Industrial Forum, Sept. 27, 1955.

${ }^{53}$ It can be argued on the other hand, however, that Congress must explicitly provide that states' law will be superseded in order to pre-empt a field traditionally considered to be within the domain of state police powers-and the 1954 act contains no such language.

"See Estep, supra note 18. 
"Doing nothing" may sound like an abdication of responsibility. It is not, however, or at least need not necessarily be so. The atomic energy industry is a new one. Concepts of standards of protection against radiation hazards have undergone many changes in recent years, and it is the opinion of experts in the field that as more experience is gained such standards will be continually re-examined and -modified..$^{55}$ A state having no or few sources of potential radiation hazards outside the scope of federal regulation or having an insufficient number of adequately trained experts in the field of radiation safety upon whom it could call to administer any program might wisely choose not to embark on any special scheme of state regulation at this time. Other factors which a state might take into consideration in determining whether regulations of any sort are desirable are: whether the private organizations to be regulated are responsible or not; whether they have already established and are enforcing adequate control measures in their own establishments; the value to be gained by a cautious policy of waiting and seeing how the programs of other states fare; and finally, of course, whether there is political pressure from constituents for regulation.

A second possible state policy would be to adopt measures to protect the state's citizens from hazards with which the AEC is not concerned. Is there, in fact, an area left untouched by federal controls? The answer is clearly "yes." Neither the act nor the regulations purport to deal with naturally occurring radioactive substances other than source materials, such as radium and radon and their daughter products; nor with radiation produced from $\mathrm{X}$-ray machines, fluoroscopic devices, and particle accelerators; nor with radioactive isotopes produced by particle accelerators and not distributed by the AEC. Nor does the AEC concern itself with health hazards connected with source materials prior to their delivery to the government or its agents for refining. These areas, then, constitute sources of potential hazard to the citizens of the states which may well deserve attention. In addition, although radioactive isotopes are made available to private users by the AEC only pursuant to licenses granted by the Isotopes Division, follow-up inspections of the users of such isotopes are made only on a spot-check basis, with priority given to the licensees who possess a large quantity of a particular isotope or who possess a particularly dangerous one. This type of inspection is used because of the large number of isotope shipments currently being made and because such inspection system has operated satisfactorily to date. ${ }^{56}$ While it is illegal to transfer or acquire AECproduced isotopes without license from the AEC, the spot-check type of inspection cannot insure that the isotopes do not pass into the possession of unlicensed persons who are not complying with the safety precautions required by the AEC. The considerations mentioned above as appropriate determinants of state action or inaction would also be applicable in this limited field of regulation.

The third possible course which a state might follow would be to adopt com-

${ }^{55}$ See generally NCRP, The Regulation of Radiation Exposure by Legislative Means (to be published in December 1955).

${ }^{50}$ See Aebersold, Address to Meeting of States' Representatives, op. cit. supra note 41a, at 18. 
prehensive radiation protection regulations overlapping the AEC regulations, with or without coverage of the additional area mentioned above. Such action would be based on the theory that although the national government's laws and regulations are to be accorded a pre-eminent status over state laws and regulations, the latter are not invalid so long as they are not inconsistent with the federal program. Some legal authority for such theory could be found in the fairly recent case of California v. Zook. ${ }^{57}$ It would seeem, however, that such coincidental regulation has little to commend it. To the extent the area is covered by federal regulation, such state action is probably useless duplication. In addition, the legal status of such action is equivocal. Prior to the Zook case, the rule had been well established that such coincident state regulation was as ineffective as conflicting state regulation; ${ }^{58}$ and the Zook case, a 5-4 decision, has never been relied upon by the Supreme Court since it was decided. Thus, it would appear to be a poor basis on which to erect a structure of state regulation in this field.

From the foregoing, it appears that the states in adopting their own health and safety regulations, would probably be best advised to limit themselves to dealing with radiation hazards outside the scope of the federal law and regulations. ${ }^{59}$ Even in this limited area, the states should take care to impose regulations not for their own sake but only for the sake of controlling hazards that actually exist; and even then, only when sufficient numbers of adequately trained personnel are available to prepare and enforce them. Overzealousness may not only be fruitless, but may, in some cases, be harmful. If, for instance, the only particle accelerator in the state is located in a large university and operated only by a competent staff, enforced compliance with detailed, overconservative health and safety regulations might well cost more in terms of lost research effort than it would provide in terms of safeguards. Types of state control over radiation protection that are already being asserted are shown in Appendix II.

Adoption of the policy of self-restraint here recommended, however, need not deny the states a significant role in controlling radiation hazards within the perimeter of AEC responsibility. The states, however, must be willing to act in the capacity of agents of the national government rather than as sovereign principals. All of the states have one or more agencies charged with responsibility for state public health and industrial health and safety. Such organizations. regularly check the state's water for impurities, its air for pollution, its industrial establishments for railings, lights, sanitary facilities, and so forth. To the extent that AEC inspectors make the same rounds while checking on uses of isotopes, or investigating concerns producing or utilizing special nuclear material, or disposing of waste materials, unnecessary

${ }^{57} 336$ U.S. 725 (1949).

${ }^{68}$ Southern Ry. v. Indiana, 236 U.S. 439 (1915); Charlestown \& Western Carolina R.R. v. Varnville Furniture Co., 237 U.S. 597 (I915).

${ }^{50}$ This policy appears to be consistent with the general position being taken by the NCRP in its forthcoming handbook, The Regulation of Radiation Exposure by Legislative Means, supra note 55. The NCRP, however, seems to entertain doubts (not shared by the writers) as to the power of the federal government to exclude the states from activity in the area federally regulated. 
duplication of effort is involved. The AEC radiation control program, thus, might well be made more efficient and its limits of effective administration extended if the AEC inspections were made by the appropriate state agency whose officials already customarily monitor the locus in question. Such a procedure would be feasible only in states where the state health department or labor department or both have at their command sufficient numbers of adequately trained personnel; and the proficiency of its personnel would of course, determine the types of inspection which could be delegated to any given state agency.

Such a procedure appears to be authorized under section $16 \mathrm{I}(\mathrm{f})$ of the 1954 act, ${ }^{00}$ which provides that the Commission may:

... with the consent of the agency concerned, utilize or employ the services . . of any government agency or any state or local government, or voluntary or uncompensated personnel, to perform such functions on its behalf as may appear desirable.

Precedent for such use of state officials to carry out federal responsibilities to provide health and safety protection against radiation hazards may be found in the administration of the Walsh-Healey Act, section $\mathrm{I}(\mathrm{e})$ of which specifies that no part of certain government contracts may be performed under substandard working conditions; ${ }^{61}$ and section 4 of which contains a clause similar to section $\mathrm{r} 6 \mathrm{x}(\mathrm{f})$ of the Atomic Energy Act of $1954{ }^{.2}$ The United States Labor Department, which is charged with responsibility for the administration of the Walsh-Healey Act, has entered into written agreements with the appropriate state administrative agencies in more than twenty-five states making the state agency the sole agent of the federal government to conduct investigations of plants in the given state to determine compliance with the federal law and administrative standards adopted for its enforcement. Such cooperative federalism under the Walsh-Healey Act points the way for effective administration of federal health and safety regulations under the Atomic Energy Act of 1954 .

The AEC should use state agencies to carry out the federal responsibilities for health and safety regulations wherever the AEC finds the state agency to be sufficiently equipped with well-trained persons to do the job. Such a procedure would eliminate unnecessary, irksome duplication, save taxpayers' money, free AEC officials for work in areas where state authorities cannot do the requisite job, and, in general, probably achieve the most effective protection against radiation hazards throughout the country.

For such a program to work, certain guideposts should be observed: the AEC must know the identity of the state officers who will be charged with federal investigations and must be satisfied with their capabilities; the AEC should pay the state agencies enough to meet the additional costs incurred by the agency in doing the AEC work; the types of inspection, the intervals between types of inspection, and

co 68 STAT. 948, 42 U.S.C.A. $\$ 220 \mathrm{r}$ (E) (Supp. I954).

${ }_{61} 49$ Stat. 2036 (I936), as amended, 56 STAT. 277 (I942), 4 I U.S.C. $\$ 35$ (e) (1946).

0249 STAT. 2038 (1936), 4 I U.S.C. $\$ 38$ (1946). 
the routine and special reports of inspection to be sent to the AEC must be clearly understood; the AEC must not undermine the state officials by making independent checks of the installations after the responsibility for them has been delegated to the state agency, except in emergency situations; enforcement authority should be retained by the AEC; and there should be a clearly designated state official responsible for administration of the state's obligations and a clearly designated AEC liaison official.

Such a program could probably be inaugurated in some states today with respect to isotope users and research reactor operators. Larger reactors, however, require a host of specialists to assess their potential hazards: physicists, engineers, sanitary engineers, meteorologists, hydrologists, and geologists in addition to health physicists. Accordingly, it does not seem likely that the AEC will delegate its responsibility for health and safety protection of such installations in the near future.

Initiative for such a program of cooperative federalism can come from the states as well as from the AEC. And now is the time for initiative. Once standard practices become adopted, inspectors hired by the AEC, and routines established, it will be almost impossible to modify the scheme. Furthermore, if there is a jurisdictional problem in the state, so that responsibility for occupational hygiene is not located in the public health agency, the AEC may be justifiably reluctant to use either the public health agency or the agency with responsibility for occupational hygiene until the two have joined forces to such an extent that the AEC may be sure that it is not involving itself in an inter-agency dispute. In a similar connection, the United States Labor Department and the United States Public Health Service have long had a written understanding with respect to their respective roles in the control and prevention of industrial health hazards. ${ }^{63}$ There is no reason why state agencies could not reach a similar understanding with respect to their respective roles in radiation protection.

\section{$\mathrm{V}$}

In summary, there are great changes rapidly taking place, both technologically and legally, in the development of atomic energy for industrial uses. The AEC still occupies a dominant position in atomic energy matters, but now there is also room for the states to formulate and implement state-wide policies, both for the encouragement of atomic industrial development within their borders and for the regulation of risks and hazards which may be unique to the industry. In the area of radiation protection, the states should take only such action as is consonant with their capabilities for effective enforcement, should cooperate with the AEC in enforcement of the comprehensive federal regulations rather than adopting conflicting or duplicating regulations, and should limit their own regulations to those hazards not covered by the AEC regulations. Other areas of state activity should be carefully

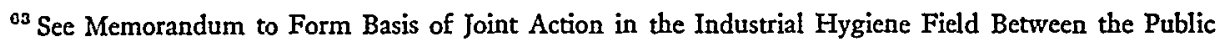
Health Service and the Department of Labor (Bureau of Labor Standards), executed and dated Sept. II, I936, reaffirmed in 1953 .
} 
examined to determine both their exact relation to atomic energy development and the changes in law, governmental structure, and state policy necessary to further the best interests of the state in question and its citizens. To coordinate the studies, to insure that they are completed, to keep the governor and all department heads abreast of developments in atomic energy within the state and without, some such office as Coordinator of Atomic Energy Activities should be created, be given the appropriate powers and financial backing necessary to do the job, and be staffed by a person of vision and determination who is capable of assuring that atomic energy developments in the state are commensurate with its potential.

\section{APPENDIX I}

Draft of an Act to Coordinate Development and Regulatory Activities Relating to the Peaceful Uses of Atomic Energy

Be it enacted by etc.

Section 1. Declaration of Policy.

a. The state of endorses the action of the Congress of the United States in enacting the Atomic Energy Act of 1954 to institute a program to encourage the widespread participation in the development and utilization of atomic energy for peaceful purposes to the maximum extent consistent with the common defense and security and with the health and safety of the public; and therefore declares the policy of the State to be-

I. To cooperate actively in the program thus instituted; and

2. To the extent that the regulation of special nuclear materials and by-product materials, of production facilities and utilization facilities, and of persons operating such facilities may be within the jurisdiction of the State, to provide for the exercise of the State's regulatory authority so as to conform, as nearly as may be, to the Atomic Energy Act of 1954 and regulations issued thereunder, to the end that there may, in effect, be a single harmonious system of regulation within the State.

b. The State of recognizes that the development of industries producing or utilizing atomic energy may result in new conditions calling for changes in the laws of the State and in regulations issued thereunder with respect to health and safety, working conditions, workmen's compensation, transportation, public utilities, life, health, accident, fire, and casualty insurance, the conservation of natural resources, including wildlife, and the protection of streams, rivers, and airspace from pollution, and therefore declares the policy of the State to be-

$x$. To adapt its laws and regulations to meet the new conditions in ways that will encourage the healthy development of industries producing or utilizing atomic energy while at the same time protecting the public interest; and

2. To initiate continuing studies of the need for changes in the relevant laws and regulations of the State by the respective departments and agencies of the State which are responsible for their administration; and

3. To assure the coordination of the studies thus undertaken, particularly with other atomic industrial development activities of the State and with the development and regulatory activities of other States and of the Government of the United States.

Comment on Section I:

The principal function of this section is to state the objectives of the state act. The section 
does not seek to set forth findings to provide the bases to sustain the constitutionality of the statute since, in aligning the enacting State's policy with that of the Federal Government, the Act should enable the State to enjoy the benefit of the findings declared by Congress in the Atomic Energy Act of 1954 .

Section 2. United States Licenses or Permits Required.

No person shall manufacture, construct, produce, transfer, acquire or possess any special nuclear material, by-product material, production facility, or utilization facility, or act as an operator of a production or utilization facility wholly within this State unless he shall have first obtained a license or permit for the activity in which he proposes to engage from the United States Atomic Energy Commission if, pursuant to the Atomic Energy Act of 1954 , the Commission requires a license or permit to be obtained by persons proposing to engage in activities of the same type over which it has jurisdiction.

Comment on Section 2:

Some question has been raised whether, in the absence of a war emergency, the Federal Government's authority reaches as far as the licensing requirements of the 1954 Atomic Energy Act would extend it. If this doubt should prove valid, a gap would exist in regulatory power. Since the very possibility that such a gap may exist invites challenge, there is need for the enactment of a statutory provision designed to close the gap without imposing regulatory burdens in this field that State Governments are not equipped to carry and without giving rise to any conflict between State and Federal authority. This is the purpose which Section 2 is intended to fulfill.

If the Federal Government requires that a license or permit be obtained for any one of the type of atomic activities listed in Section 2 whenever that activity is carried out within the jurisdiction of the Federal Government, no person will be permitted to conduct that activity wholly within the State without first getting a Federal license or permit. It will therefore be of no advantage to a person seeking to escape compliance with Federal licensing requirements to raise jurisdictional issues.

If the Constitutional authority of the Federal Government is held to cover the listed activities, even when conducted wholly within a State, the State would have concurrent authority with the Federal Government unless the latter were held to have pre-empted the field.

If the Federal Government is held to have pre-empted the field, Section 2 will have been of no legal effect. However, it will not have interfered as a practical matter with the exercise of Federal authority, and it will have served as a deterrent to any search for a loophole in regulatory authority.

The question may be raised whether this section represents an unconstitutional delegation of future legislative power to the Federal Government by the State Government. Undoubtedly, from time to time, the Federal Government would announce new license requirements subsequent to the enactment of the State Act, and it may be argued that these new requirements represent a change in State law. Section 2 seems reasonably safe from attack, however, since it merely uses the possession of the Federal license as a fact indicating that the possessor is a fit person to engage in the activity to which the license applies. Section 2 is like a statute conferring certain privileges on persons who have been admitted to the bars of other States. Statutes of this sort are not considered unconstitutional by the fact that the requirements for admission to the bar may be changed by the other States in the future. And a State may condition the transport of intoxicating liquor through its territory on the fact that the consignee in another state may lawfully receive it. Carter v. Virginia, 321 U.S. I3I (1944). 
The Opinion of the Justices, 239 Mass. 606, x33 N.E. 453 I92I deals with a legislative attempt to punish under State law violations of the Federal prohibition latvs which, of course, were subject to change by the Congress. This was held invalid as an unlaw ful delegation of legislative power. One of the sections declared invalid contained a provision relating to Federal permits that was like that in Section 1 . However, the same section also declared violations of the Federal law to be violations of State law and so was clearly invalid on the general ground of objection stated by the Court. There was no occasion to test the separability of the section's provisions, and so the good part fell with the bad.

The activities covered by Section 2 do not extend to "source materials," e.g. uranium ore. The handling of these is not attended by danger. The application of regulations is likely to turn on minor variations in ore content. Because of the resulting uncertainty, the adoption of State laws or regulations relating to source materials might, in effect, embarrass activities involving ores that contain minute quantities of uranium. Absent a showing or a need for protection, no action now seems called for.

Section 3. Conduct of Studies Concerning Changes in Laws and Regulations with a Vietv to Atomic Industrial Development.

Each of the following departments and agencies of the State Government is directed to initiate and to pursue continuing studies as to the need, if any, for changes in the laws and regulations administered by it that would arise from the presence within the State of special nuclear materials and by-product materials and from the operation herein of production or utilization facilities, and, on the basis of such studies, to make such recommendations for the enactment of laws or amendments to law administered by it, and such proposals for amendments to the regulations issued by it, as may appear necessary and appropriate.

a. The Department of Public Health, particularly as to hazards, if any, to the public health and safety.

b. The Department of Labor, particularly as to hazardous working conditions, if any.

c. The Workmen's Compensation Commission, particularly as to the time and character of proof of claims of injuries and the extent of the compensation allowable therefor.

$d$. The Department of Public Highways, particularly as to the transportation of special nuclear materials and by-product materials on highways of the State.

$e$. The Public Utilities Commission, particularly as to the transportation of special nuclear materials and by-product materials by common carriers not in interstate commerce and as to the participation by public utilities subject to its jurisdiction in projects looking to the development of production or utilization facilities for industrial or commercial use.

$f$. The Department of Insurance, particularly as to the insurance of persons and property from hazards to life and property resulting from atomic development.

g. The Department of Conservation, particularly as to the hazards, if any, to the natural resources of the State, including wildlife, and as to the protection, if necessary, of rivers, streams, and airspace from pollution.

$h$. Such other departments and agencies (including departments and agencies of political subdivisions of the State) as the Governor may direct and for the purposes specified by him.

Comment on Section 3:

This section is premised on the supposition that study will disclose a need for a number of changes in existing laws and regulations to take care of new conditions created by atomic development for peaceful uses. The statutory directive will justify the use by the 
several departments and agencies of their personnel in making the studies thus called for, a step that some of them might otherwise be reluctant to take.

In a number of states, important responsibilities affecting atomic energy developments may be vested in the governments of cities, counties and other political subdivisions of the State. For example, city planning and zoning boards and building commissioners exercise powers that could affect the location and construction of reactors within municipal limits. The language in brackets in paragraph $(h)$ is intended to enable local governments to be brought within the range of the planning activities if this should be thought desirable. In any particular State, special provisions may be needed to reflect the legal relationships existing between the State and its subdivisions.

The names of departments and agencies used in this draft are given simply as examples. The list would not be accurate in any single State.

Section 4. Coordination of Studies and Development Activities.

a. The Governor and Council shall appoint a citizen of this State to serve as adviser to the Governor with respect to atomic industrial development within the State; as coordinator of the development and regulatory activities of the State relating to the industrial and commercial uses of atomic energy; and as deputy of the Governor in matters relating to atomic energy, including participation in the activities of any committee formed by the New England States to represent their interest in such matters and also cooperation with other States and with the Government of the United States. The person so appointed shall have the title of Coordinator of Atomic Development Activities.

b. The Coordinator of Atomic Development Activities shall have the duty of coordinating the studies, recommendations, and proposals of the several departments and agencies of the State (and its political subdivisions) required by Section 3 of this Act with each other and also with the programs and activities of the Department of Industrial Development of the State. So far as may be practicable, he shall coordinate the studies conducted, and the recommendations and proposals made, in this State with like activities in the New England and other States and with the policies and regulations of the United States Atomic Energy Commission. In carrying out his duties, he shall proceed in close cooperation with the Department of Industrial Development.

c. The several departments and agencies of the State (and its political subdivisions) which are directed by Section 3 of this Act to initiate and pursue continuing studies are further directed to keep the Coordinator of Atomic Development Activities fully and currently informed as to their activities relating to atomic energy. No regulation or amendment to a regulation applying specifically to an atomic energy matter which any such department or agency may propose to issue shall become effective until 30 days after it has been submitted to the Coordinator, unless, upon a finding of emergency need, the Governor by order waives all or any part of this 30-day period.

d. The Coordinator of Atomic Development Activities shall keep the Governor and Council and the several interested departments and agencies informed as to private and public activities affecting atomic industrial development and shall enlist their cooperation in taking action to further such development as is consistent with the health, safety and general welfare of this State.

e. The Coordinator of Atomic Development Activities shall be paid a salary of $\$$ per annum.

\section{Comment on Section 4:}

This section is premised on the proposition that what is everybody's business is nobody's business and therefore seeks to make sure that atomic development and regulation is some- 
body's business. The office of the Coordinator of Atomic Development Activities is proposed so that at least one person in a central position in the State Government will be responsible for seeing that the way is cleared for atomic devclopment and that this is done without jeopardizing the public interest. If substantially similar statutes were enacted in all the New England states, the Coordinators could cooperate in developing a vigorous and sensible regional program. In any event, it is to be hoped that the present New England Committee on Atomic Energy will be succeeded by a similar body charged with encouraging a regional approach to the problems of atomic industrial development and any Coordinators appointed in the New England States could work closely with that organization.

Since the Coordinator's duties would cut across the fields of activity of many departments in the State Government, there is some risk that he would be by-passed by departments that were not alive to the need for cooperation. This problem would be accentuated if it is decided to bring departments and agencies of county, city and other local governments within the range of the Coordinator's activities. Accordingly, to make sure that the Coordinator can discharge his function effectively, it is provided in paragraph (c) that he be kept fully informed and given advance notice of proposed regulations so that he may make his views heard before possibly detrimental action can be taken. This requirement may be waived by the Governor. The provision has some analogy in the various provisions for advance notice of proposed action that must be given to the Joint Committee on Atomic Energy in Congress. However, the flow of information is not to be wholly in one direction. Paragraph (d) requires the Coordinator to keep the various agencies informed of atomic developments.

The work of the Coordinator would be on a full-time basis in some States, but in others part-time service would probably suffice. No attempt has therefore been made in paragraph (e) to specify either a salary for the Coordinator or the terms of his service.

Section 5. Injunction Proceedings.

Whenever, in the opinion of the Attorney General, any person is violating or is about to violate Section 2 of this Act, the Attorney General may apply to the appropriate court for an order enjoining the person from engaging or continuing to engage in the activity violative of this Act and upon a showing that such person has engaged, or is about to engage in any such activity, a permanent or temporary injunction, restraining order, or other order - may be granted.

\section{Comment on Section 5:}

No criminal penalties have been provided for violation of Section 2. The cases, if any, are sure to be rare, and are likely to be intended to test the scope of Federal controls rather than to violate willfully a legal requirement known to be valid. To meet this situation, an injunction proceeding should suffice.

Section 6. Funds Provided.

There is hereby authorized to be appropriated the sum of $\$$ for the salary of the Coordinator of Atomic Development Activities and for secretarial, travel, printing, and other necessary expenses incurred by him in the performance of his duties.

Section 7. Definitions.

As used in this Act,

a. The term "atomic energy" means all forms of energy released in the course of nuclear fission or nuclear transformation.

b. The term "by-product material" means any radioactive materials (except special 
nuclear materials) yielded in or made radioactive by exposure to the radiation incident to the process of producing or utilizing special nuclear materials.

c. The term "production facility" means (I) any equipment or device capable of the production of special nuclear material in such quantity as to be of significance to the common defense and security, or in such manner as to affect the health and safety of the public; or (2) any important component part especially designed for such equipment or device.

d. The term "special nuclear material" means (I) plutonium and uranium enriched in the isotope 233 or in the isotope 235 , and any other material which the Governor declares by order to be special nuclear material after the United States Atomic Energy Commission has determined the material to be such; or (2) any material artificially enriched by any of the foregoing.

$e$. The term "utilization facility" means ( $I$ ) any equipment or device, except an atomic weapon, capable of making use of special nuclear materials in such quantity as to be of significance to the common defense and security, or in such manner as to affect the health and safety of the public, or peculiarly adapted for making use of atomic energy in such quantity as to be of significance to the common defense and security, or in such manner as to affect the health and safety of the public; or (2) any important component part especially designed for such equipment or device.

$f$. The term "operator" means any individual who manipulates the controls of a utilization or production facility.

Comment on Section 7:

The definitions contained in paragraphs (a) and (b) are indentical to the corresponding ones in the Atomic Energy Act of x954. However, the definitions of "production facility" and "utilization facility" in paragraphs (c) and (e) respectively have been broadened by eliminating the provisions in the Federal Act which give the Commission power to narrow the category by rule. After the word "device" in the first line of (c) and "weapon" in the second line of (e), the Federal Act includes the phrase "determined by rule of the Commission to be" and also, after the word "device" at the end of each definition, it includes the phrase "as determined by the Commission.". Both these phrases have been eliminated.

The reason these definitions have been revised in this way is that their retention in their original form would have left the applicability of Section 2 to depend on rules of the Atomic Energy Commission to be made in the future. This might have led to a decision that Section 2 represent an unconstitutional delegation of legislative power by the State to the Federal Government.

Fortunately, for the purposes of Section 2, there is no need to narrow the definitions as closely as the Federal Act requires since in no case would Section 2 impose any actual requirement for an intra-state activity unless the Federal Act required a license or permit for the same type of activity. The scope of the Federal Act thus becomes the final determinant of the scope of Section 2, but in a way that is believed to be constitutional.

In Section 3 the same terms are used in describing the areas of study to be pursued by the several departments and agencies of the State Government. Despite the fact that the areas are defined in this Act more broadly than the corresponding areas are defined in the Federal Act, there would be no reason for the departments and agencies to carry their studies to the logical extremes permitted by these State definitions.

The definition of "special nuclear material" in paragraph (d) differs from the Federal definition by giving the Governor power to enlarge the category, a power conferred by 
the Federal Act on the Atomic Energy Commission. However the Governor is authorized to take this action only after the Commission has added the new material or materials to the category. This definition could not be treated as were the definitions of the facilities since it provided no broad category which the Commission had pover to narrow. Fortunately, as a practical matter, there will in all probability be very few additions to the list so the Governor will not be burdened by the task of keeping the State Act in line with the Federal in this respect.

The Federal definition also explicitly excludes "source material," an exclusion that seems to have been added out of excess of caution. To introduce it here would require a definition of "source material." The precaution seems unnecessary.

Revised Diaft

May 15, 1955.

\section{APPENDIX II $\dagger$}

\begin{tabular}{|c|c|c|c|c|c|c|c|c|c|c|c|c|c|c|c|}
\hline State & 1 & 2 & 3 & 4 & 5 & 6 & 7 & State & 1 & 2 & 3 & 4 & 5 & B & 7 \\
\hline Alabama.. & .. & $\cdots$ & $\cdots$ & $\cdots$ & $\cdots$ & $\mathrm{X}$ & $\cdots$ & Nebraska. . . . . . . . . . & .. & . & .. & .. & . & $\mathbf{X}$ & . \\
\hline Arizona.... & $\ldots$ & $\ldots$ & .. & .. & .. & .. & 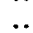 & Nerada.............. & .. & .. & $\ldots$ & .. & .. & .. & . \\
\hline Arkansas........... & . & .. & .. & $\ldots$ & $\mathrm{x}$ & .. & $\mathrm{X}$ & New Hampshire. .... & .. & .. & .. & .. & $\mathbf{X}$ & $\mathbf{X}$ & .. \\
\hline California......... & $\mathrm{X}$ & .. & .. & $\mathrm{X}$ & .. & $\mathrm{X}$ & .. & New Jersey.......... & .. & $\mathbf{X}$ & $\mathbf{X}$ & .. & .. & $\mathbf{x}$ & . \\
\hline Colorado............. & . & .. & .. & . & $x$ & $\mathrm{X}$ & $\mathrm{X}$ & New Mexico........... & .. & .. & .. & .. & $\ldots$ & $\mathbf{X}$ & $\mathbf{x}$ \\
\hline Connecticut......... & $\mathrm{X}$ & .. & $\mathbf{X}$ & .. & $\mathbf{X}$ & $X$ & .. & New York............ & $\mathrm{X}$ & $\mathbf{X}$ & .. & * & .. & $X$ & $\mathrm{X}$ \\
\hline Delaware...... & .. & $\mathrm{X}$ & .. & .. & .. & .. & .. & North Carolina.. & .. & .. & .. & .. & .. & .. & . \\
\hline Florida..... & . & $\cdots$ & .. & $\ldots$ & $X$ & $\cdots$ & .. & North Dakota... & .. & .. & .. & $\ldots$ & .. & .. & $\cdots$ \\
\hline Georgia.. & .. & $\cdots$ & .. & .. & .. & $\mathrm{X}$ & $\bar{X}$ & Ohio................ & . & . & . & .. & $\cdots$ & $\because$ & . \\
\hline Idaho..... & .. & . & .. & .. & $\ldots$ & $\mathrm{X}$ & $\mathbf{x}$ & Oklahoma........... & .. & . & .. & .. & .. & $\mathbf{x}$ & . \\
\hline Mllinois..... & $\ldots ;$ & .. & .. & .. & .. & $x$ & .. & Oregon.............. & . & $\mathbf{X}$ & .. & . & $\ldots$ & $\mathbf{X}$ & $\because$ \\
\hline Indiana.... & $\ldots$ & .. & .. & . & . & .. & .. & Pennsylvania... & . & . & $\ldots$ & $*$ & * & 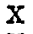 & $\mathbf{x}$ \\
\hline Iowa...... & .. & .. & .. & .. & .. & $\because$ & .. & Rhode Island... & . & . & .. & .. & $\cdots$ & $\mathbf{X}$ & $\mathbf{X}$ \\
\hline Fansas.... & $\cdots$ & $\cdots$ & $\mathbf{X}$ & . & . & $x$ & $\mathbf{X}$ & South Carolina. . & . & . & .. & $\cdots$ & . & $\cdots$ & $\cdots$ \\
\hline Kentucky.. & .. & .. & * & * & .. & .. & .. & South Dakota... & .. & .. & .. & .. & . & . & .. \\
\hline Louisiana. . & .. & . & $\cdots$ & .. & $\cdots$ & .. & $\mathbf{x}$ & Tennessee..... & .. & $\because$ & .. & .. & . & $\because$ & $\because$ \\
\hline Maine..... & .. & .. & .. & .. & .. & .. & .. & Texas.......... & .. & $X$ & . & .. & . & $\mathbf{X}$ & $\mathrm{X}$ \\
\hline Maryland...... & .. & .. & .. & . & .. & $X$ & .. & Utah.......... & .. & . & . & .. & .. & .. & * \\
\hline Massachusetts.. & $X$ & .. & .. & . & $\cdots$ & $X$ & .. & Vermont....... & .. & .. & . & -. & . & . & $\cdots$ \\
\hline Michigan..... & .. & .. & .. & . & .. & $x$ & .. & Virginia....... & .. & . & .. & .. & $\because$ & $\because$ & . \\
\hline Minnesota. . & .. & .. & . & .. & .. & $X$ & .. & Washington.... & .. & $\ldots$ & .. & .. & $\mathbf{x}$ & $\mathbf{X}$ & $\cdots$ \\
\hline Mississippi. . & .. & .. & .. & .. & . & $\bar{X}$ & . & West Virginia ......... & .. & . & $\mathrm{x}$ & $\cdots$ & $\because$ & $\because$ & $\cdots$ \\
\hline Missouri.... & .. & .. & .. & .. & .. & $\mathbf{X}$ & $\cdots$ & Wisconsin........ & $\cdots$ & . & .. & .. & $X$ & $\mathbf{X}$ & $\ldots$ \\
\hline Montana.... & .. & .. & . & . & . & .. & .. & Wyoming............ & -. & $x$ & . & .. & $\cdots$ & . & . \\
\hline
\end{tabular}

Cormow 1: States with statutes specifically authorizing radiation control regulations or governing radiation hazards.

Counas 2: States with comprehensive public health regulations for control of ionizing radiation.

Condur 3: States with public health regulations for control of specified types or aspects of ionizing radiation.

Coudun 4: States with comprehensive industrial hygiene regulations for control of ionizing radiation.

Conoun 5: States with industrial hygiene regulations for control of specified types or aspects of ionizing radiation.

Conusov 6: States reporting satisfactory, informal cooperation with the AEC in matters of inspection and control of isotopo users.

Coutun 7: States in which injuries resulting from excessive radiation exposure are compensable under workmen's compengation Inwg.

*Regulations have been proposed but not adopted.

†See also Administralite Problems in Radiation Protection, Nucleonics, Dec. 1954, p. 8, in which Drs. Tabershaw and Harris exploro the essential elements of radiation protection regulations of a number of governmental; industrial, and other organizations. 